\title{
Adaptation of Attitudes Towards to Vaccine Scale to Turkish, Investigation of Validity and Reliability
}

\author{
Aşıya Illişkin Tutumlar Ölçeğinin Türkçe’ye Uyarlanması, \\ Geçerlik ve Güvenirliğinin Incelenmesi
}

\author{
Didem Özümit' ${ }^{1}($ ID $)$, Hatice Yıldırım Sarı²(ID) \\ ${ }^{1}$ Malatya Yeşilyurt Hasan Çalık State Hospital, Malatya, Turkey \\ ${ }^{2}$ Department of Child Health and Diseases Nursing, Izmir Katip Çelebi University Faculty of Health Sciences, Izmir, Turkey
}

Cite this article as: Özümit D, Yıldırım Sarı H. Adaptation of attitudes towards to vaccine scale to Turkish, investigation of validity and reliability. J Pediatr Inf 2021;15(3):e165-e174.

\section{Abstract}

Objective: This study was designed to adapt the Turkish version of the Attitudes Towards Vaccine Scale, which was developed to determine the social attitudes towards vaccination, and to make its validity and reliability in Turkish.

Material and Methods: Data were collected from 208 health professionals (41.6\%) and 292 (58.4\%) parents, including physicians, nurses, lab technicians, dietitians, pharmacists, social workers, psychologists $(\mathrm{n}=$ 500).

Results: When the corrected item correlation values of the scale were examined, it was seen that all items were above 0.30 and all of these items were suitable for factor analysis evaluation. The factors of the scale items were determined according to Kaiser-Meyer-Olkin $(\mathrm{KMO}=0.856)$ criterion and Bartlett sphericity test $(x 2=2671.831 ; p<0.001)$. According to exploratory factor analysis results, two components explained $51.32 \%$ of the total variance. In the study, Cronbach's a value was found to be 0.853 for 14 items and the internal consistency value was found to be high. Tukey Nonadditivity Analysis of Variance was used to determine whether the items were collectible and the items were collectable $(F=$ 202.252; $\mathrm{p}<0.001$ ).

Conclusion: The Turkish version of the Attitudes Towards Vaccine Scale consisted of 14 items with 2 factors. The scale is a valid and reliable tool in the Turkish language that can be used to determine social attitudes towards vaccination.

Keywords: Vaccination attitude scale, vaccine, validity-reliability
Öz

Giriş: Bu çalışma aşıya ilişkin toplumsal tutumları belirlemek amacıyla geliştirilmiş olan Aşıya İlişkin Tutumlar Ölçeği'ni Türkçe'ye uyarlamak, Türkçe geçerlik ve güvenirliğini yapmak amacıyla planlanmıştır.

Gereç ve Yöntemler: Araştırmada hastanede çalışan hekim, hemşire, laborant, diyetisyen, eczacı, sosyal hizmet uzmanı, psikolog olmak üzere 208 sağlık profesyonelinden (\%41.6) ve 292 (\%58.4) ebeveynden veri toplanmıştır ( $\mathrm{n}: 500)$.

Bulgular: Ölçeğin düzeltilmiş toplam madde korelasyonu değerleri incelendiğinde tüm maddelerin 0.30 değerinin üstünde yer aldığı ve bu maddelerin tamamının faktör analizi değerlendirmesi için uygun olduğu görülmüştür. Ölçek maddelerinin faktörlerine Kaiser-Meyer-Olkin $(\mathrm{KMO}=0.856)$ ölçütü ve Bartlett küresellik testine $(X 2=2671.831 ; p<$ 0.001 ) göre karar verilmiştir. Açımlayıcı faktör analizi sonuçlarına göre iki bileşen toplam varyansın \%51.32'sini açıklamaktadır. Çalışmada 14 ölçek maddesi için Cronbach a değeri 0.853 olarak elde edilmiş ve maddeler arası iç tutarlılık değeri yüksek bulunmuştur. Maddelerin toplanabilir olup olmadığı Tukey Toplanamazlık (Nonadditivity) Varyans Analizi ile değerlendirilmiş ve maddelerin toplanabilir olduğu görülmüştür ( $F=$ 202.252; $\mathrm{p}<0.001$ ).

Sonuç: Aşıya Yönelik Tutumlar Ölçeği'nin Türkçe formu 2 faktörlü, 14 maddeden oluşmuştur. Ölçek aşıya ilişkin toplumsal tutumları belirlemek için kullanılabilecek Türk dilinde geçerli ve güvenilir bir araçtır.

Anahtar Kelimeler: Aşıya yönelik tutum ölçeği, aşı, geçerlik güvenilirlik

Correspondence Address/Yazışma Adresi

Didem Özümit

Sağlık Bakanlığı Malatya Yeşilyurt Hasan Çalık Devlet Hastanesi,

Malatya Devlet Hastanesi,

Malatya-Türkiye

E-mail: didemozumit@gmail.com 


\section{Introduction}

Immunization is one of the most effective public health instruments to prevent infectious diseases which play a vital role in the development of health, to eradicate diseases, and hence, to diminish the rates of diseases and mortality (1). Vaccines are one of the most important discoveries in the history of science in terms of having a positive effect on human health. Immunization, in the fight against infectious diseases, is accepted, without dispute, as an effective method of protection in the scientific world (2).

Thanks to immunization practices, the death and possibility of getting infected with a disease of 2-3 million people are prevented annually. Moreover, individuals in all age groups are protected from serious life-threatening diseases requiring hospitalization, including diphteria, tetanus, hepatitis $A$ and hepatitis $B$, mumps, measles, rubella, pneumococcal diseases, polio, and rotavirus diarrhea. Even though immunization has reached $90 \%$ in many countries around the world, it is quite low in developing countries, and around $29 \%$ of deaths in children aged under 5 years occur due to vaccine-preventable diseases (3). World Health Organization (WHO) announced as its 2020 objective to eradicate polio, measles, and maternal and neonatal tetanus and to develop vaccines against malaria, tuberculosis and AIDS and extend their use (4).

Vaccination schedule is planned according to each country's population variables. The National Immunization Program of Turkey was last updated in 2019. According to the updated vaccination schedule, 13 different vaccines are administered to children aged 0-18 years. According to the 2017 Health Statitistic of the Ministry of Health, the rates of vaccine administration for diphteria, acellular pertussis, tetanus, inactive polio, haemophilus influenzae B, BCG, hepatitis B, mumps, measles and rubella, and conjugated pneumococcus vary between 93\%-96\% (5). Despite such positive progress, there has been some skepticism over vaccines, and in addition to the dispute on vaccine efficiency, these views have suggested that immunization could cause the development of serious pathologies in individuals and have found vaccines responsible for diseases without a cause. This attitude has brought to light the anti-vaccination movement. Anti-vaccination first appeared during the studies of Edward Jenner, and E. Massey, a religious scholar, argued and advocated that diseases were sent to humanity God as a form of punishment and that it would be sacrilegious to prevent diseases and immunization would be eqiuvalent to follow Satan's lead. The state of Masschusetts was the first U.S. state to enforce mandatory immunization for school-aged children in 1855. However, objections to mandatory immunization led to an active and organized anti-immunization movement. It was asserted that mandatory immunization was a practice against human rights (6).
The continuity and increase of the success of immunization can be provided by the high-rate of immunization globally. Nonetheless, as in all around the world in recent years, immunization rates have tended to fall since parents have started to refuse getting their children vaccinated. It is considered that popularization of the anti-vaccination movement will lead to epidemics in vaccine-preventable diseases affecting community immunization $(7,8)$.

Anti-vaccination movement gained more popularity in the last eight years and the number of families refusing to get their children vaccinated reached 183 in 2011, 980 in 2013, 5400 in 2015, 12.000 in 2016, and the number of cases regarding vaccine-refusal was reported as 23.000 in 2018 (9). The rate of measles vaccination, which was $98 \%$ in 2016 , dropped to $97 \%$ in 2017, and similarly, the rate of diphteria, tetanus, and pertussis vaccination dropped to $96 \%$ in 2017 while it was $98 \%$ in 2016 (10). Measles incidence reached 0.1 in 100.000 persons while it was 0.01 in 2016. It has been underlined that should cases of vaccine-refusal reach 50.000 , it would be inevitable to have epidemics (9).

In the world, vaccination rates vary from country to country. While it is between $79-80 \%$ in countries such as Afghanistan, Pakistan, India, and Nigeria, despite being over $90 \%$ in Europe and the USA, a fall at an average of $3 \%$ was determined in some regions of Europe and the USA between 2012 and 2016 (11). There has been a fall in measles vaccination rates in recent years. For instance, it dropped to $85 \%$ in Italy and 88\% in Europe. As regards the 2017 data, immunization rates of diphteria, tetanus and pertussis dropped to $92 \%$ in Europe and $91 \%$ in the USA (12).

Even though state policies are still effective in attitudes towards vaccines, along with religious and philosophical influences, attitudes are being affected by the widespread use of technology, social media and mass media. In research conducted on the matter at hand, the communication of healthcare professionals with patients and the transmit of correct information have been shown to be reliable and effective in developing positive attitudes (13).

There have been many studies conducted on the reasons for vaccine refusal, deferral or hesitation. Though study results have differences, factors affecting attitudes towards vaccines have been summed up under four main headings as religious reasons, personal beliefs and philosophical reasons, safety concerns, and desire to obtain more information (14).

\section{Objective}

The increase in supporting the anti-vaccination movement in Turkey and in the number of parents refusing to get their children vaccinated necessitates studies oriented at developing positive societal attitudes on vaccination. This study aimed to adapt into Turkish the Attitudes Scale on Vaccine, 
which has been developed to determine societal attitudes on vaccine, and to perform its validity and reliability in Turkish.

\section{Materials and Methods}

Type of the Research: The research was designed as descriptive and methodological.

Time and Place of the Research: The research was conducted between November 1 $1^{\text {st }}, 2018$ and May 1 $1^{\text {st }}, 2019$ in the Tepecik Education and Researh Hospital in Izmir, Turkey.

Research Sample: For methodological research, it is recommended to choose 5 to 10 folds of the number of scale items in the calculation of sample volume or for factor analysis, 200 subjects are evaluated as "moderate", 300 as "good", 500 as "very good" and 1000 as "excellent" (15). No sample selection was performed during data collection, and it was aimed to reach the whole sample by complete count method ( $n: 500)$. It was planned to compose the sample of healthcare professionals and parents, 50\% each. Using random improbable sampling method, data were collected from a total of 208 (41.6\%) heathcare professionals including physicians, nurses, laboratory technicians, dieticians, pharmacists, social services specialists, and psychologists who willingly participated in the study, met the study inclusion criteria, and could be reached during daytime or nightime shifts and 292 (58.4\%) parents. From the research population of 500 people, 52 were determined to do a re-test, and the form was filled out again 15 days after the first data had been collected. Ret-test data were collected from 52 people who wrote pseudonym on the first survey form. Re-test data were selected among the healthcare professionals due to reachability of re-test data.

\section{Includion Criteria to the Research}

- To be employed in the healthcare institution where the research is to be made or to have a child inpatient or outpatient at the age group of 0-18 years in the healthcare institution where the research is to be made

- To be fluent in Turkish (to communicate orally and in writing)

- To be over 18 years of age

\section{Data Collection Tools}

As the data collection tools in the research, a socio-demographic form and Attitudes Scale towards Vaccine were used.

The Socio-Demographic Question Form: The form was prepared by the researcher. It includes 12 items with questions regarding age, sex, marital status, education level, profession, years of employment, and income level.

Attitudes Scale towards Vaccine: The scale was developed by Cvjetkovic et al. in 2017 and is comprised of 14 items (16). Scale items, in general, covers individuals' attitudes, be- haviour, and thoughts on vaccine practices. The scale is in a 5-Likert type and is scored as 1 "I totally disagree" and 5"I totally agree". Reverse scoring was implemented in items containing negative expressions. Scores between 14-32 are accepted as negative attitude, 33-51 as moderate attitude and 52-70 as positive attitude. The Cronbach alpha value of the original scale is 0.90 . Construct validity factor analysis was carried out on the basis of Kaiser-Meyer-Olkin (KMO 0.89) and Bartlett test (x2-1684.210, df-91, $\mathrm{p}<0.01)$. As a result of the factor analysis, a 3 -factor construct was detected explaining $66 \%$ of the item variance (core values $46.11,12.22$ and 7.85 ). The validity and reliability analysis of the scale was performed with students at the faculties of Medicine, Law and Electrical Engineering in the University of Belgrade.

\section{Data Collection Process}

Upon obtaining approval to use the scale and following the Turkish adaptation of the scale and receiving institutional approvals, data collection tools were implemented by the researcher between January 1st and May 1st, 2019. The research was conducted at times when hospital administration allowed. During data collection, the researcher visited patient rooms and working stations of the hospital personnel. The participants were briefly informed by the researcher on the research subject prior to filling out the survey forms, and the vaccine form and scale were verbally explained. The participants were asked not to write their names on the survey forms. Only the participants that were going to re-reply the survey forms were asked to write their pseudonyms. The survey forms were delivered to healthcare workers during their working hours and to next-of-kin of the patients during their visit to hospital and when they were available. Questions forwarded to the researcher by the participants were answered. The participants were given 20 minutes to answer the questions. Out of a population of 500 participants, data were collected from 52 participants again 15 days after the initial collection of the survey forms for scale test-re-test data.

Turkish Validity and Reliability Analysis of the Attitudes Scale towards Vaccine: The validity analysis of language and content of the scale was performed taking into account the method and processes recommended by $\mathrm{WHO}$ for the translation and adaptation of tools in another language (17). Turkish translation of the scale originally written in English was carried out by 5 language experts, and the translated form was reviewed and edited by the researcher and her advisor. Back translation of the scale was performed by three academics that understood and spoke both languages. Following back translation, the items on the original form and the back-translated form were compared and edited. The edited scale was sent to 10 experts for expert opinion and scoring done by the experts were analysed with Kendall W test and Content Validity Index. Prior to the data collection phase, the scale was applied to 10 individuals different 
from the sample, parts that were difficult to understand were reviewed again, and the scale reached its final version. The results of this pilot study were not included into the research.

\section{Data Analysis}

SPSS 22 (Statistical Package for Social Sciences) package program was used for data analysis. For the evaluation of scale validity, Cronbach Alpha co-efficient was used for internal consistency between the items, Tukey Nonadditivity Variance Analysis was used to find out if the items were addable, Kaiser-Mayer-Olkin criterion and Bartlett sphericity test were used to find out if the scale items could be factored, and principal components factor extraction and varimax rotation methods were used for exploratory factor analysis to put forth factor construct $(18,19)$. SPSS AMOS 22 program was used for confirmatory factor analysis. For the reliability analysis of the scale, internal consistency (Cronbach Alpha and item total correlation) and itime nvariance method (t test and intraclass correlation coefficient) were used. Statistical significance was set at $p<0.05$ with $95 \%$ confidence interval.

\section{Ethical Aspect of the Research}

Ethics board approval of the study was obtained with decision no. 2018/14-15 dated 22.11.2018 from Tepecik Education and Researh Hospital non-invasive Clinical Research Ethics Board. Prior to the commencement of the study, approval from Cvjetkovic was obtained via e-mail to perform the validity and reliability of the scale in Turkish. Institutional approval was received from Tepecik Education and Research Hospital to collect research data. Consent was obtained from all volunteering participants.

\section{Limitations to the Research}

The research was conducted at a single hospital considering that it hosted employees and patients with different socio-cultural backgrounds. Due to the fact that next-of-kin of most of the patients was the mothers, the sample was mainly composed of females. Sample characteristic is the limitation of the research.

\section{Results}

Forty-six point eight percent of the individuals participating in the study were non-healthcare professional mothers and $34.6 \%$ were healthcare professional mothers. Of the participants, $82.8 \%$ were females and $92.4 \%$ were married. Of the participants, $26.0 \%$ were housewives, $21.8 \%$ were nurses, and $7.0 \%$ were teachers. Of the spouses of the participants, $14.0 \%$ were labourers, $9.8 \%$ were government employees, $7.8 \%$ were self-employed, $7.8 \%$ were private sector employees, and $7.6 \%$ were teachers. Of the participants, $41.0 \%$ had a bachelor's degree, $16.4 \%$ were high-school graduates, and $11.8 \%$ had an associate degree. Of the participants' spouses, $40.7 \%$ had a bachelor's degree, $19.6 \%$ were high-school graduates, and $11.2 \%$ were secondary school graduates.
Mean age of the participants was $36.16 \pm 7.98$ years. Mean total employment year of the healthcare workers was $13.5 \pm$ 7.29 years, and mean employment year in the current institution was $7.8 \pm 6.15$ years. Of the participants, $5 \%(n=25)$ had a total income of under $1000 \mathrm{TL}, 18.5 \%(n=92)$ between $1001-2500$ TL, 20.8\% ( $n=103)$ between $2501-4000$ TL, 20.6\% $(n=102)$ between $4001-5500 T L, 10.9 \%(n=54)$ between 5501 $7000 \mathrm{TL}$ and $24.2 \%(n=120) 7001 \mathrm{TL}$ and over. Of the healthcare personnel, $57.1 \%(n=120)$ served both adult and child patients, $21.9 \%(\mathrm{n}=46)$ served only child patients and $21 \%(\mathrm{n}=$ 44) only adult patients. Of the non-healthcare workers, $78.7 \%$ $(n=74)$ obtained information on vaccines from healthcare workers, $14.9 \%(n=14)$ from the media, and $6.4 \%{ }^{\prime}(n=6)$ from social circle (neighbors-relatives) (the total number of people replying to this question is 94 ).

\section{Findings Regarding the Validity of the Attitudes Scale towards Vaccine}

It was seen on Kendall W analysis performed over 10 expert opinions conducted prior to the scale's implementation on the participants that there was no significant difference (Kendall's $\mathrm{W}=1133 ; \mathrm{p}=0.189$ ) and expert opinions were similar. For the evaluation of expert opinions, Davis technique was used to calculate Content Validity Index (CVI) and found as 0.94. In light of the expert opinions, some expressions were changed and various omissions and additions were made to make the language plain and simple to understand. The author developing the scale was informed of the changes and approval was obtained.

Total value of the scale for 500 participants in the research varied between 19 and 70 (mean=51.64 \pm 8.4 , minimum $=19$, maximum $=70$, median $=51$ ). When correlation values of the total edited items were examined, it was seen that all items were above the value of 0.30 and all were suitable for factor analysis. Initially, factors were determined by performing exploratory factor analysis on the data. Confirmatory factor analysis was conducted on factors found on exploratory factor analysis. Kaiser-Meyer-Olkin $(\mathrm{KMO}=0,856)$ criterion and Bartlett sphericity test $(X 2=2671.831 ; p<0.001)$ were used to decide on the factorability of the scale items. Since KMO coefficient was 0,856 , the result was excellent. Therefore, sample size of the research is sufficient. The significance of Bartlett sphericity test confirms the performability of factor analysis. On exploratory factor analysis to present factor construct, main components factor extraction and varimax rotation methods were used. Accroding to the exploratory factor analysis results, two components expressed $51.32 \%$ of the total variance. Eigenvalue for the first and second components was 25.904 and 25.416, respectively. Table 1 shows factor loads.

According to the obtained factor loads, the scale is composed of 2 factors containing 14 questions. Considering the meaning of the items in the factors, the factors were named to match the original scale. 
Table 1. Factor Loads for Exploratory Factor Analysis and Internal Consistency Statistics of the Items

\begin{tabular}{|l|c|c|}
\hline & Factor Loads & Attitude \\
\hline Items & Thought & 0.615 \\
\hline A1 & & \\
\hline A2 & 0.681 & \\
\hline A3 & 0.744 & 0.689 \\
\hline A4 & 0.750 & 0.683 \\
\hline A5 & & 0.709 \\
\hline A6 & & 0.714 \\
\hline A7 & & 0.560 \\
\hline A8 & & 0.627 \\
\hline A9 & & 0.613 \\
\hline A10 & & \\
\hline A11 & & \\
\hline A12 & & \\
\hline A13 & 0.774 & \\
\hline A14 & 0.800 & \\
\hline
\end{tabular}

Table 2. Confirmatory factor analysis adaptive values

\begin{tabular}{|c|c|c|c|c|c|}
\hline Model & NPAR & CMIN & DF & $p$ & CMIN/DF \\
\hline Standard model & 32 & 234.087 & 73 & .000 & 3.207 \\
\hline Saturated model & 105 & .000 & 0 & & \\
\hline \multicolumn{2}{|l|}{ Model } & RMR & GFI & AGFI & PGFI \\
\hline \multicolumn{2}{|l|}{ Standard model } & .057 & .938 & .911 & .652 \\
\hline \multicolumn{2}{|l|}{ Independent model } & .317 & .408 & .317 & .354 \\
\hline Model & NFI Delta 1 & RFI Rho 1 & IFI Delta 2 & TLI Rho 2 & $\mathrm{CFI}$ \\
\hline Standard model & .913 & .892 & .939 & .923 & .938 \\
\hline Saturated model & 1.000 & & 1.000 & & 1.000 \\
\hline Independent model & .000 & .000 & .000 & .000 & .000 \\
\hline \multicolumn{2}{|l|}{ Independentmodel } & .240 & .232 & .248 & .000 \\
\hline
\end{tabular}

Confirmatory Factor Analysis (CFA) was applied to the factors determined by the exploratory factor analysis in the adaptation of the scale into Turkish and the following results were achieved:

As seen in Table 2, as per the adaptive values of $\mathrm{X} 2 / \mathrm{df}=$ $3.207<5, \mathrm{RMR}=0.057<0.08,0.085<\mathrm{GFI}=0.938,0.90<\mathrm{IFI}=$ $0.939,0.90<\mathrm{CFI}=0.938$, RMSEA $=0.066<0.08$, the model shows excellent adaptation to the data. Hence, the validity of the Attitude Scale towards Vaccine found by exploratory factor analysis was confirmed by confirmatory factor analysis. According to the analysis result, adaptation values were found as $\mathrm{CFI}=0.938, \mathrm{GFI}=0.938, \mathrm{NFI}=0.913, \mathrm{RMR} 0.057$ and $\mathrm{RMSEA}=$ $0.066(p<0.05)$. Figure 1 shows each item's standardized regression weights as per Confirmatory Factor Analysis (CFA).

Findings Related to the Reliability of the Attitudes Scale towards Vaccine

For 14 scale items of the study, Cronbach a value was found as 0,853 and inter-item internal consistency value was found high. Turkey Nonadditivity Variance Analysis was used to determine if the items were addable, and it was seen that they were $(F=202.252 ; p<0.001)$. Item total score correlations of the items varied between 0.418 ile 0.569 . (Table 3 ). 


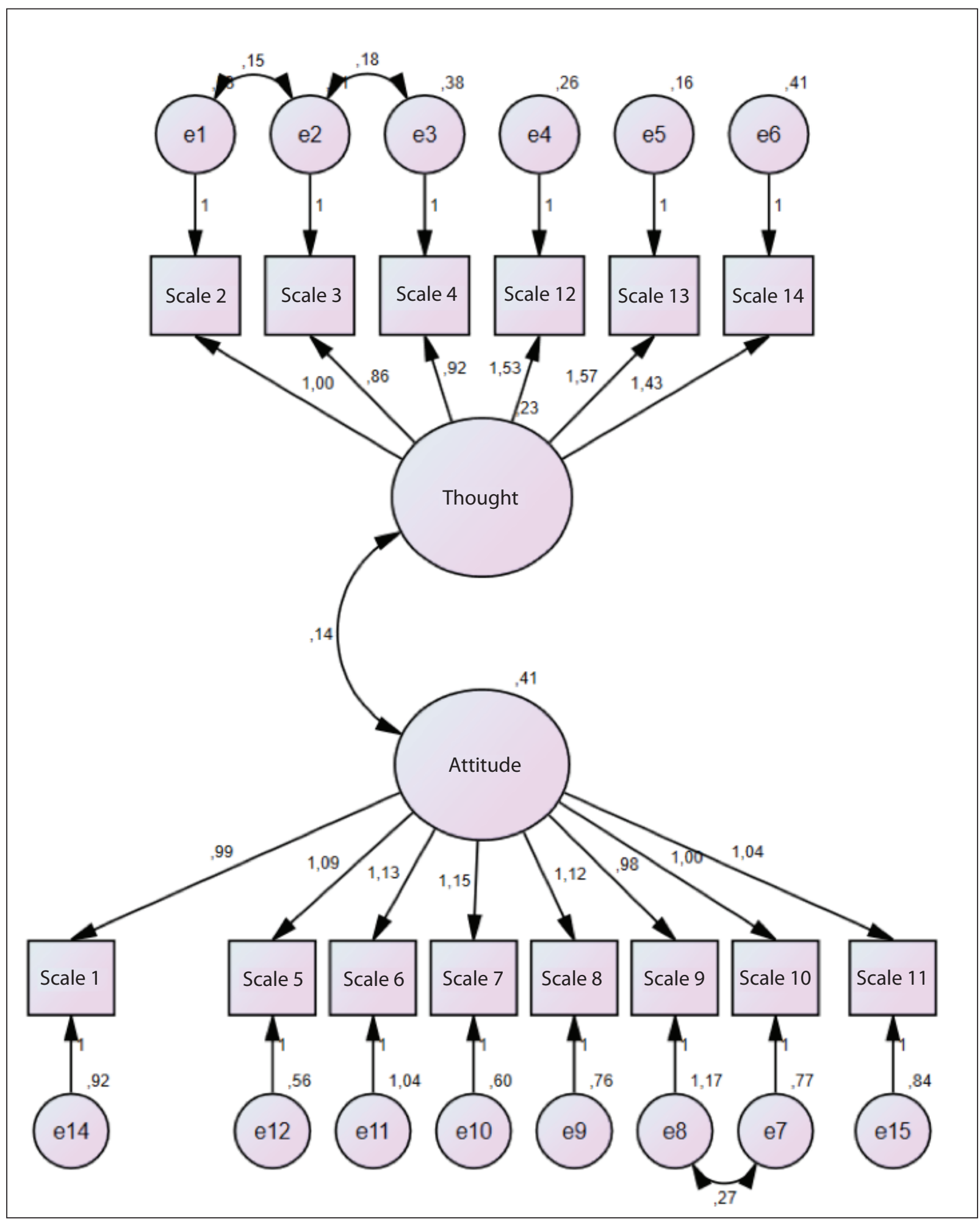

Figure 1. Confirmatory factor analysis of the attitudes scale towards vaccine.

Table 4 shows the Cronbach Alpha values of the subscales. Attitude subscale Cronbach Alpha value was 0.870 , and Thought subscale Cronbach Alpha value was 0.900 .

As seen in Table 5, correlation between the forms on splithalf analysis was 0.725 .
Evaluation of the Attitudes Scale towards Vaccine Regarding Time Invariance

In the research, 52 participants were included into re-test, and Cronbach Alpha value for consistency of the 52 participants and 14 items was found as 0,863. Table 6 and Table 7 
Table 3. Edited total item correlation and cronbach alpha value when the item is deleted $(n=400)$

\begin{tabular}{|l|c|c|}
\hline Items & Edited Total Iten Correlation & Cronbach Alpha value when the Item is deleted \\
\hline A1 & 0.456 & 0.847 \\
\hline A2 & 0.468 & 0.846 \\
\hline A3 & 0.492 & 0.845 \\
\hline A4 & 0.449 & 0.847 \\
\hline A5 & 0.569 & 0.840 \\
\hline A6 & 0.418 & 0.850 \\
\hline A7 & 0.564 & 0.840 \\
\hline A8 & 0.491 & 0.845 \\
\hline A9 & 0.485 & 0.846 \\
\hline A10 & 0.569 & 0.840 \\
\hline A11 & 0.517 & 0.843 \\
\hline A12 & 0.528 & 0.843 \\
\hline A13 & 0.566 & 0.841 \\
\hline A14 & 0.512 & 0.843 \\
\hline
\end{tabular}

Table 4. Cronbach alpha values of the subscales

\begin{tabular}{|l|c|}
\hline Subscale & Cronbach Alpha \\
\hline Thought subscale & 0.90 \\
\hline Attitude subscale & 0.87 \\
\hline
\end{tabular}

present intra-class correlation coefficient (ICC) and comparison performed for preliminary and re-test results.

The difference between the preliminary test and last test values according to Table 6 was not found statistically significant ( $t=1.019 ; p=0.313)$. Values of the preliminary and last tests are similar. In Table 7, preliminary and last test values by the participants were found highly consistent $(\mathrm{ICC}=0.979 ; \mathrm{p}<$ $0.001)$. The scale was found reliable as per these results.

\section{Discussion}

In this research conducted to perform the Turkish validity and reliability of the Attitudes Scale towards Vaccine, data were collected from 500 participants who were and were not healthcare workers, and the Cronbach Alpha value of the 14 -item scale was detected as 0.853 , and intra-item internal consistency value was found high. When edited total item correlation values were examined, it was seen that all items were above the value of 0,30 and all were suitable for factor analysis. Factorability of the scale items were decided upon

Table 5. Split-half reliability analysis data of attitudes scale towards vaccine

\begin{tabular}{|c|c|c|c|c|}
\hline Scale Section & Mean & SD & Cronbach's Alpha & Correlation between the Forms \\
\hline First Section (Items 1,2,3,4,5,6,7) & 26.1280 & 4.31890 & 0.728 & 0,725 \\
\hline Second Section (Items $8,9,10,11,12,13,14$ ) & 25.5180 & 4.75172 & 0.768 & \\
\hline \multicolumn{4}{|l|}{ Spearman-Brown Coefficient } & 841 \\
\hline \multicolumn{4}{|l|}{ Guttman Split-Half Coefficient } & 838 \\
\hline
\end{tabular}

Table 6. Comparison of preliminary test and re-test values

\begin{tabular}{|l|c|c|c|c|c|}
\hline & Preliminary test & Last test & Difference & $\mathbf{~ t}$ & $\mathbf{p}$ \\
\hline Scale & $53.03 \pm 8.44$ & $53.28 \pm 8.74$ & $-0.25 \pm 1.79$ & 1.019 & 0.313 \\
\hline
\end{tabular}

Table 7. Intra-class correlation coefficient and 95\% confidence limits for preliminary test and last test

\begin{tabular}{|l|c|c|c|}
\hline & ICC & $\mathbf{9 5 \%}$ Confidence Limit for ICC & p \\
\hline Preliminary test-Last test & 0.979 & $0.963-0.988$ & \\
\hline ICC: Intra-class correlation coefficient.
\end{tabular}


Kaiser-Meyer-Olkin $(\mathrm{KMO}=0.856)$ criterion and Bartlett sphericity test $(X 2=2671.831 ; p<0.001)$. According to the exploratory factor analysis results, the scale with two components expressed $51.32 \%$ of the total variance. Regarding model adaptive values obtained on confirmatory factor analysis, the model showed excellent consistency to the data. The findings present Turkish validity of the scale $(18,20)$. The difference between the preliminary and last tests were not statistically significant $(t=1.019 ; p=0.313)$. Values of the preliminary and last tests were similar. Values of the preliminary and last tests were found highly consistent by the participants $($ ICC $=0.979$; $p<0.001)$. According to these results, the scale is reliable.

There are those believing that vaccines protect health and those that do not, and a part of the society even blames vacciens for some diseases. Within the content of the vaccines, mercury is the material shown and blamed as the reason for all diseases. Mercury has different forms of half-life in the body as ethyl mercury and methyl mercury. Thiomersal found in vaccines is an ethyl mercury compound. In the 2002 report published by the Global Vaccine Safety Committee of the World Health Organization, it was reported that half-life of ethyl mercury was shorter than one week, could not pass the blood-brain barrier, and was digested in 4-9 days, and in the end, it was impossible for it to accumulate in the body like other mercury compounds and cause some chronic diseases (21). Although many studies have been conducted to accept or deny the relation between thiomersal and neuro-developmental diseases, thiomersal was decided to be removed from the content of the vaccines by the USA Public Health Service and American Pediatric Academy in 1999 (22). The USA Mental Development Service retrospectively reviewed children applying due to autism between the years 1999 and 2001 to find out if thiomersalin caused autism. According to the results of this research, a significant decrease was not found following the ban of thiomersalin use in vaccines in children applying due to autism between 1995 and 2007, and according to these results, it was concluded that there was no relation between thiomersal and autism (23). It has been observed in the world that statements expressing that materials found in vaccines may cause neurological diseases like autism and multiple sclerosis may lead to different opinions in individuals. Anti-vaccination campaigns carried out by asserting these reasons reach the public quickly with the help of media and affect vaccination rates. Thus, determining the society's attitude towards vaccines will lead to studies aimed at developing positive attitudes in them.

\section{Conclusion}

In this research conducted to perform the Turkish validity and reliability of the Attitudes Scale on Vaccine, the Cronbach Alpha value of the 14-item scale was detected as 0.853 . The difference between the preliminary and last tests were not statistically significant $(t=1.019 ; p=0.313)$. Values of the pre- liminary and last tests were similar. Values of the preliminary and last tests were found highly consistent by the participants $(I C C=0.979 ; p<0.001)$. According to these results, the scale is reliable. In light with the findings of the research, it is believed that the scale can be used to detect the attitudes and thoughts of the public towards the vaccine and to determine the factors affecting vaccination. Repeating this research in different societies with different socioeconomic level and conducting studies investigating the relation with different independent variables can be recommended.

According to our study results, individuals obtain information on vaccines from healthcare professionals. Based on this fact, we can say that individuals trust healthcare professionals. Depending on this trust, reinforcing positive attitudes of the healthcare professionals towards vaccination and carrying out training and education programs aimed at developing positive attitude towards vaccination in midwives, nurses, physicians, and parents can be recommended.

Ethics Committe Approval: The study was approval obtained from SBÜ İzmir Tepecik Health Application Center (Date: 22.11.2018, Decision no: 2018/14-15).

Informed Consent: Patient consent was obtained.

Peer-review: Externally peer-reviewed.

Author Contributions: Concept - DÖ; Design - DÖ, HYS; Supervision - HYS; Resource - DÖ; Data Collection and/or Processing - DÖ; Analysis and/or Interpretation - DÖ; Literature Search - DÖ; Critical Review - HYS.

Conflict of Interest: All authors declare that they have no conflicts of interest or funding to disclose.

Financial Disclosure: The authors declared that this study has received no financial support.

\section{References}

1. Haverkate M, D'Ancona F, Giambi C, Johansen K, Lopalco PL, Cozza V, Appelgren E. On behalf of the VENICE project gatekeepers and contact points. Mandatory and Recommended Vaccination in the EU, Iceland and Norway: Results of the VENICE 2010 Survey on the Ways of Implementing National Vaccination Programmes. EuroSurveill 2010;17:22. [CrossRef]

2. Plotkin S. History of vaccination, National Academy of Sciences 2014;111:12283-7. [CrossRef]

3. World Health Organization (WHO). State Of The World's Vaccines And Immunizationh ttp://www.who.int/immunization/sowvi/en/Third Edition. Accessed date: 12.02.2018. [CrossRef]

4. Healty People. Immunization and Infectious Diseases. Available from: https://www.healthypeople.gov/2020/topics-objectives/topic/immunization-and-infectiousdiseases Accessed date: 10.05.2019. [CrossRef]

5. Sağlık İstatistikleri Yıllığı. Available from: https://www.saglikaktuel. com/d/file/trsbsiy2014.pdf Accessed date: 12.02.2018. [CrossRef]

6. Scarpelli G. Nothing in nature that is not useful: the anti-vaccination crusade and the idea of 'harmonianaturae' in Alfred Russel Wallace 1992;7:109-30. [CrossRef] 
7. Dubé E, Vivion M, Mac Donald N E. Vaccine hesitancy, vaccine refusal and the anti-vaccine movement: influence, impact and implications. Expert Rev Vaccines 2015;14: 99-117. [CrossRef]

8. Jacobson RM. Vaccination Refusa land Parental Education: Lessons Learnt. Med scape 2010: http://www.medscape.com/viewarticle/723931. [CrossRef]

9. T.C. Sağlık Bakanlığı Sağlık Bilgi Sistemleri Genel Müdürlüğü. Sağlık Istatistikleri Yıllığı 2017 Haber Bülteni, 2018. [CrossRef]

10. OECD. Child Vaccination Rates. Available from: https://data.oecd.org/ healthcare/child-vaccination-rates.htm Accessed date: 01.08.2019. [CrossRef]

11. World Health Organization (WHO). http://www.who.int/immunization/monitoring_surveillance/data/gs_eurprofile.pdf?ua=1 Data received as of 2017-Jul-11. Accessed date: 28.05.2019. [CrossRef]

12. OECD. Child vaccination rates. Diphtheria, tetanus, pertussis/Measles, $\%$ of children, 2015. Available from: https://data.oecd.org/healthcare/ child-vaccination-rates.htm. Accessed date: 27.07.2018. [CrossRef]

13. Avcı E. Çocukluk Dönemi Aşılarına İlişkin Karşılaştırmalı Bir Analiz: Amerika Birleşik Devletleri ve Türkiye. Özgürlük Araştırmaları 2017;9:535. [CrossRef]

14. McKee C, Bohannon K. Exploring the Reasons Behind Parental Refusal of Vaccines. J Pediatr Pharmacol Ther JPPTOff J PPAG 2016;21:104-9. [CrossRef]

15. Tavşancıl E. Tutumların Ölçülmesi ve SPSS ile Veri Analizi. 5. Basım, Nobel Yayıncilık, Ankara, 2014:19-51. [CrossRef]
16. Cvjetkovic SJ, Jeremic VL, Tiosavljevic DV. Knowledge and attitudes toward vaccination: A survey of Serbian students, Journal of Infection and Public Health 2017; 10: 649-56. [CrossRef]

17. World Health Organization (WHO). http://www.who.int/substance abuse/research_tools/translation /en/print.html (08.05.2018). World Health Organization [WHO] (2008b). Process of Translation and Adaptation of Instruments. [CrossRef]

18. Tinsley Howard EA, Tinsley DJ. Uses of factor analysis in counseling psychology research. J Counsel Psych 1987:34;414. [CrossRef]

19. Akgül A. Tıbbi Araştırmalarda Istatistiksel Analiz Teknikleri "SPSS Uygulamaları" (3), Emek Ofset, Ankara, 2005.[CrossRef]

20. Merenda, Peter F. A Guide to the Proper Use of Factor Analysis in the Conduct and Reporting of Research: Pitfalls to Avoid. Measurement and Evaluation in Counseling and Development 1997:156-64. [CrossRef]

21. Schechter $R$, Grether JK. Continuing increases in autism reported to California's developmental services system: mercury in retrograde. Arch Gen Psychiatry 2008;65(1):19-24. [CrossRef]

22. Gerber JS, Offit PA. Vaccines and autism: a tale of shifting hypotheses. Clin Infect Dis 2009;48(4):456-61. [CrossRef]

23. T.C. Sağlık Bakanlığı. Aşılar ile Otizm Arasında İlişki Var mı? Available from: https://asi.saglik.gov.tr/genel-bilgiler/46-a\%C5\%9F\%C4\%B1larile-otizm-aras\%C4\%B1nda-ili\%C5\%9Fki-var-m\%C4\%B1d\%C4\%B1r. html Accessed date: 25.08.2019. [CrossRef] 
Addition 1. The original scale

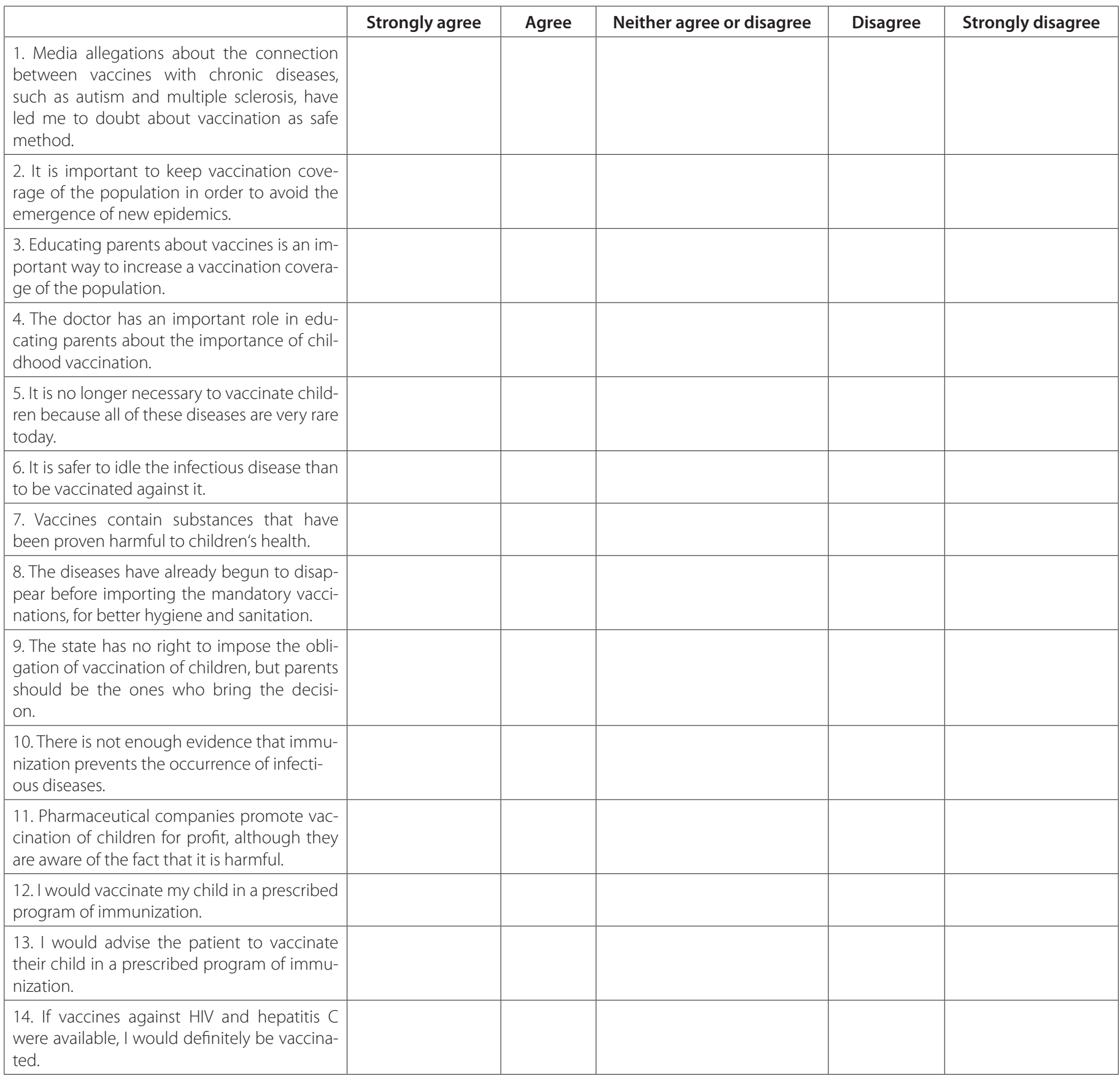

